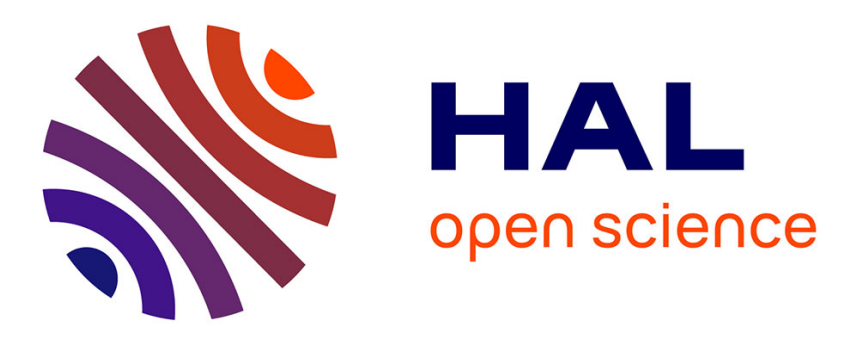

\title{
Environmental influence on relative palaeointensity estimates from Holocene varved lake sediments in Finland
}

Eeva Haltia-Hovi, Current Address, Norbert Nowaczyk, Timo Saarinen

\section{- To cite this version:}

Eeva Haltia-Hovi, Current Address, Norbert Nowaczyk, Timo Saarinen. Environmental influence on relative palaeointensity estimates from Holocene varved lake sediments in Finland. Physics of the Earth and Planetary Interiors, 2011, 10.1016/j.pepi.2010.12.002 . hal-00727170

\author{
HAL Id: hal-00727170 \\ https://hal.science/hal-00727170
}

Submitted on 3 Sep 2012

HAL is a multi-disciplinary open access archive for the deposit and dissemination of scientific research documents, whether they are published or not. The documents may come from teaching and research institutions in France or abroad, or from public or private research centers.
L'archive ouverte pluridisciplinaire HAL, est destinée au dépôt et à la diffusion de documents scientifiques de niveau recherche, publiés ou non, émanant des établissements d'enseignement et de recherche français ou étrangers, des laboratoires publics ou privés. 


\section{Accepted Manuscript}

Title: Environmental influence on relative palaeointensity

estimates from Holocene varved lake sediments in Finland

Authors: Eeva Haltia-Hovi, current address, Norbert

Nowaczyk, Timo Saarinen

PII:

DOI:

Reference:

To appear in:

Received date:

Accepted date:
S0031-9201(10)00251-7

doi:10.1016/j.pepi.2010.12.002

PEPI 5367

Physics of the Earth and Planetary Interiors

Please cite this article as: Haltia-Hovi, E., address, , Nowaczyk, N., Saarinen, T., Environmental influence on relative palaeointensity estimates from Holocene varved lake sediments in Finland, Physics of the Earth and Planetary Interiors (2010), doi:10.1016/j.pepi.2010.12.002

This is a PDF file of an unedited manuscript that has been accepted for publication. As a service to our customers we are providing this early version of the manuscript. The manuscript will undergo copyediting, typesetting, and review of the resulting proof before it is published in its final form. Please note that during the production process errors may be discovered which could affect the content, and all legal disclaimers that apply to the journal pertain. 
Title: Environmental influence on relative palaeointensity estimates from Holocene varved lake sediments in Finland

Eeva Haltia-Hovi ${ }^{1}$, current address $^{2}$, Norbert Nowaczyk ${ }^{2}$, Timo Saarinen ${ }^{1}$

${ }^{1}$ Department of Geology, FI-20014 University of Turku, Finland

${ }^{2}$ Helmholtz Centre Potsdam, GFZ German Research Centre for Geosciences, Section 5.2

Climate Dynamics and Landscape Evolution Telegrafenberg, D-14473 Potsdam, Germany

Authors: E. Haltia-Hovi*, N. Nowaczyk and T. Saarinen

*corresponding author, contact information:

Eeva Haltia-Hovi

Helmholtz Centre Potsdam

GFZ German Research Centre for Geosciences

Section 5. 2 Climate Dynamics and Landscape Evolution

Telegrafenberg

D-14473 Potsdam

Germany

Email: eemaha@gfz-potsdam.de

Tel.: +49 (0)331 2881397

Fax.: +49(0)331288 1302

Keywords: relative palaeointensity; varves; lake sediments; Holocene; Finland 


\section{Introduction}

Reconstructing past variations in geomagnetic palaeointensity provides information with various applications. These include e.g. modelling of the evolution of the geomagnetic field moment (Korte and Constable, 2005) and reconstructions of past solar activity by investigations of cosmogenic isotopes, whose production is in part modulated by the strength of the geomagnetic field (Thouveny et al., 1993; Beer 2000; Snowball and Muscheler, 2007). Importantly, globally synchronous variations in geomagnetic palaeointensity provide chronological markers for correlating different geological archives (Channell et al., 2009).

Variations in geomagnetic field intensity have been observed for the last two centuries (Courtillot and Le Mouël, 1988; Stern, 2002). In order to look further back in time, different archaeological and geological proxies have been employed to collect data on the variations in palaeointensity. These include extrusive rocks and baked archaeological artefacts carrying thermoremanent magnetisation (TRM), which allows the reconstruction of palaeointensity in absolute terms (Teanby et al., 2002; Kovacheva et al., 2004; Donadini et al., 2007). Unfortunately, the occurrence of these materials is scattered in space and time, and their precise dating may be ambiguous (Clark et al., 1988). Continuous information on the behaviour of the geomagnetic field can be obtained from investigations of marine and lacustrine sedimentary sequences, which may serve as records of relative palaeointensity (Meynadier et al., 1994; Williams et al., 1998; Guyodo and Valet 1999). Whereas marine sediments allow the reconstruction of long-term relative palaeointensity records, lacustrine and some river estuarine sediments provide more highly resolved palaeointensity data due to their generally higher deposition rates. The basic assumption underlying reconstruction of relative palaeointensity in sediments is that the measured natural remanent magnetisation (NRM) is in linear proportion to the concentration of magnetic minerals and the ambient magnetic field strength at the time of deposition (Kent, 1973; Tucker, 1981). To correct for the long-core variations in the magnetisability of sediments, laboratory-induced magnetisations and different types of remanence are applied to estimate the concentration of magnetic minerals. These include low-field magnetic susceptibility $(\kappa)$, anhysteretic remanent magnetisation (ARM) and saturation isothermal magnetisation (SIRM). However, other physical factors such as hydrodynamic and gravitational processes, particle flocculation, changes in the concentration, type and mineralogy of clay minerals and salinity, may influence the acquisition of remanence, and thereby the intensity of magnetisation in sediments (Shcherbakov and Shcherbakova, 1983; Lu et al., 1990; Katari and Tauxe, 2000; Katari and Bloxham, 2001; Franke et al., 2004; Mitra and Tauxe, 2009).

Reconstruction of relative palaeointensity requires uniform magnetic properties, which have been reviewed by Tauxe (1993) and Valet (2003). Despite the rather strict constraints, relative palaeointensity records have been proposed in several recent studies, which have encouraged further investigations on relative palaeointensity using high-resolution sedimentary records (St-Onge et al., 2003; Richter et al., 2006; Snowball et al., 2007). In some cases, the reliability of relative palaeointensity reconstructions has been questioned due to unremoved climatic and/or environmental imprint (Weeks et al., 1995; Schwarz et al., 1996; Lund and Schwarz, 1999; Kok, 1999; Brachfeld and Banerjee, 2000; Nowaczyk et al., 2001; Frank et al., 2002). 
This study presents the results of reconstructing relative palaeointensity from the sediments of two small neighbouring lakes in eastern Finland during the last 5100 years using conventional bulk normalisation procedures. The high quality of the palaeomagnetic directional records from these lakes has been recently discussed by Haltia-Hovi et al. (2010a). The investigated sediments are annually laminated, i.e. varved, providing an independent and precise chronology (Haltia-Hovi et al., 2007, Haltia-Hovi et al., 2010a). The results discussed document the complex relationship between relative palaeointensity estimates using standard normalisation techniques and unremoved environmental imprints, and the necessity of careful consideration of the environmental biases in the proposed relative palaeointensity estimates from similar sediments.

\section{Study sites, varve formation and sediment coring}

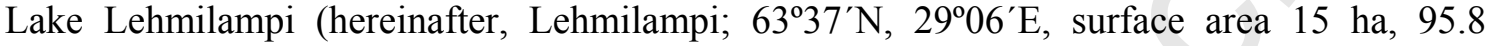

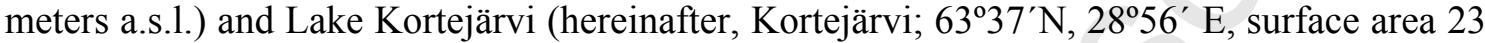
ha, 105.3 meters a.s.1.) are two small boreal lakes located in Northern Karelia, Eastern Finland (Fig. 1). The bedrock of the study area is part of the Fennoscandian Shield, which belongs to the multiply deformed late Archaean basement characterised by tonalites, trondhjemites and migmatites (Luukkonen, 2005). Climate has clear seasonal contrasts, and mean temperatures in January and July are $-10{ }^{\circ} \mathrm{C}$ and $+16{ }^{\circ} \mathrm{C}$, respectively (Helminen 1987). The investigated sediments are annually laminated gyttja clay or clay gyttja sediments. Varve formation and preservation in these lakes results from the combined effects of climatically regulated seasonal changes in sediment sources together with deficiency of dissolved oxygen in the deepest areas of the basins. Flooding following snowmelt in the spring transports fine detrital matter to lakes, and from summer to winter, fine autochthonous and allochthonous organic matter deposits in the lake bottom. The absence of bottom-dwelling fauna in the oxygen-poor hypolimnion enables the preservation of distinctive clastic-organic varve couplets in these lakes (e.g. Haltia-Hovi et al., 2007). The sediment cores investigated have been retrieved using piston corers from an ice platform in spring in 2006 (Table 1). Cores were opened in laboratory and sediment was sampled into palaeomagnetic sampling cubes $\left(6.8 \mathrm{~cm}^{3}\right)$ at $2.5 \mathrm{~cm}$ intervals. Laboratory procedures relating to sediment core handling and sampling are described in detail in Haltia-Hovi et al. (2010a).

\section{M agnetic measurements and mineral magnetic characteristics}

Magnetic measurements were carried out in the Laboratory for Paleo- and Rock magnetism at the Helmholtz Centre Potsdam GFZ in Germany. Magnetic measurements are summarised in Table 2, and more detailed information on the measurements is presented in Haltia-Hovi et al. (2010a). The standard induced and installed magnetisations, including low-field magnetic susceptibility ( $\kappa)$, anhysteretic remanent magnetisation (ARM) and saturation isothermal remanent magnetisation, were employed to estimate the concentration of the magnetic minerals. The discussion on mineral magnetic and relative palaeointensity results is limited to the sediment core LL-I from Lehmilampi and to core KJ-A from Kortejärvi for the following reasons: 1) sediments are continuously varved, providing a highly resolved chronology; 2) sediments have apparently uniform mineral magnetic properties. Reconstructing relative palaeointensity requires a sediment magnetic assemblage dominated by pseudo single-domain (PSD) magnetite with concentration variations within an order of magnitude (King et al., 1983; Tauxe, 1993). Moreover, palaeomagnetic directional record should be of high quality, and the reconstructed relative palaeointensity record should not show correlation neither with the magnetic parameters nor lithological variations (Brachfeld and Banerjee, 2000; Lund and Schwarz, 1999). Stability of the NRM and palaeosecular directional variations recorded in the sediments of Lehmilampi and Kortejärvi during the last 10000 years were recently discussed 
by Haltia-Hovi et al. (2010a). Progressive NRM demagnetisation in ten alternating field (AF) steps (from 5 to $100 \mathrm{mT}$ ) showed univectorial decay towards the origin after the removal of secondary magnetisations in low fields, usually by the $20 \mathrm{mT}$ AF demagnetisation step. Multiple cores yielded a highly consistent palaeomagnetic directional record in comparison with PSV records from Fennoscandia and Europe, allowing the building of North Karelian palaeomagnetic stacks of mean inclination and declination for the Holocene (Haltia-Hovi et al., 2010a). Variations recorded in the mineral magnetic parameters, mirroring changes in the concentration, grain size and mineralogy of magnetic minerals and their environmental interpretation in the Lehmilampi and Kortejärvi sediments during the Holocene, have been recently discussed in Haltia-Hovi et al. (2010a) and Haltia-Hovi et al. (2010b). A summary of selected mineral magnetic parameters drawn from these papers is briefly reviewed here for evaluating the suitability of the sediments for relative palaeointensity reconstructions.

\subsection{M ineral magnetic characteristics of Lehmilampi}

Selected mineral magnetic parameters for Lehmilampi are shown in Fig. 2. Judging from the similarity of the NRM, $\kappa$, ARM and SIRM profiles, the intensity of NRM mainly responds to the concentration of magnetic minerals. Concentration of magnetic minerals varies by a factor of less than 2, 2.5 and 2 for $\kappa$, ARM and SIRM, respectively. The S-ratio, calculated here as $0.5^{*}\left[1-\left(\mathrm{IRM}_{-100 \mathrm{mT}} / \mathrm{SIRM}_{1000 \mathrm{mT}}\right]\right.$, is conventionally interpreted to indicate relative variations in low and high coercivity minerals, where 0 (1) indicates the sole presence of haematite (magnetite) (e.g. Frank and Nowaczyk, 2008). The high values in S-ratio, nearly throughout $\geq 0.9$, and the median destructive field of ARM ( $\mathrm{MDF}_{\mathrm{ARM}}$ ) ranging between 38 and $43 \mathrm{mT}$ support the interpretation of magnetic assemblage dominated by fine PSD sized magnetite (Maher, 1988). Stepwise acquisition of IRM of selected samples from the core LL-I indicated that about $90 \%$ of the IRM is obtained after exposing samples to magnetising fields ranging from 100 to $130 \mathrm{mT}$, suggesting magnetic mineralogy dominated by a ferrimagnetic mineral, most probably magnetite (Haltia-Hovi et al., 2010b). The interparametric ratio $\kappa_{\mathrm{ARM}} / \mathrm{SIRM}$ serves as a magnetic grain size proxy, and it is sensitive to the concentration of single domain (SD) magnetite. Higher (lower) values in $\kappa_{\mathrm{ARM}} / \mathrm{SIRM}$ denote relatively finer (coarser) magnetic grain size in a magnetic assemblage dominated by magnetite (Maher, 1988). Values in $\kappa_{\mathrm{ARM}} / \mathrm{SIRM}$ are high, which indicate contribution of SD sized magnetite in the magnetic assemblage. Variations in the magnetic grain size proxies and mass normalised ARM (not shown here) closely respond to the concentration of organic matter as defined by measuring total organic carbon (TOC) in Lehmilampi (Haltia-Hovi et al., 2010b). The similarity of mineral magnetic properties of Lehmilampi sediments in comparison with other lakes, where SD sized magnetosomes produced by magnetotactic bacteria have either been shown (Snowball, 1994; Kim et al., 2005) or suspected (Ojala and Saarnisto, 1999; Snowball et al., 2002; Geiss et al., 2004; Paasche et al., 2004) to be a part of the sediment magnetic assemblage, is believed to mirror the contribution of magnetosomes in the Lehmilampi sediments. The fairly uniform magnetic properties in the deep basin of Lehmilampi, as represented by core LL-I, are assumed to be suited for reconstructing variations in relative palaeointensity.

\subsection{M ineral magnetic characteristics of Kortejärvi}

Fig. 3 presents the same magnetic parameters from Kortejärvi as was shown for Lehmilampi. The concentration of magnetic minerals, as indicated by $\kappa$, ARM and SIRM, varies by factors less than 2.5, 2.5 and 2, respectively. NRM shows a general decreasing trend, corresponding to variations in ARM and SIRM. According to hysteresis parameters, bulk magnetic grain size tightly clusters in the finer end of the PSD range, with $M_{\mathrm{sr}} / \mathrm{M}_{\mathrm{s}}$ and $\mathrm{B}_{\mathrm{cr}} / \mathrm{B}_{\mathrm{c}}$ ranging from 0.27 to 0.34 and from 1.8 to 2.1, respectively (Haltia-Hovi et al., 2010a). Parameters 
indicating coercivity, or $\mathrm{H}_{\mathrm{r}}$ (coercivity of remanence; 35.7-38.2 mT), $\mathrm{MDF}_{\mathrm{ARM}}(42-46 \mathrm{mT})$ and S-ratio (mostly $\geq 0.9$ ), showed only small variations, which was interpreted to indicate a uniform magnetic assemblage dominated by SD to fine PSD magnetite (Maher, 1988; Peters and Dekkers, 2003). The grain size indicative parameter $\kappa_{\mathrm{ARM}} / \mathrm{SIRM}$ shows varying but consistently high values, indicative of SD magnetite (Maher, 1988). Unfortunately, the lack of TOC data from Kortejärvi precludes making detailed inferences of the relationship between magnetic parameters and concentration of organic matter in sediments. However, such homogenous mineral magnetic properties may suggest that at least part of the magnetic minerals in the sediments is of bacterial origin. In the light of mineral magnetic properties, $\mathrm{KJ}-\mathrm{A}$ has potential to yield a relative palaeointensity record.

\section{Varve chronology of Lehmilampi and K ortejärvi sediments}

Varve chronologies for Lehmilampi and Kortejärvi sediments have been established by semiautomatic varve counting using x-ray densitometry in combination with digital image analysis (Haltia-Hovi et al., 2007; Haltia-Hovi et al., 2010a). Relative mean x-ray density provides information on annual compositional variations in the deposited sediment. This parameter responds to sediment compositional variations, with higher (lower) density values relating to higher (lower) relative proportion of detrital matter in the sediment. On average, Lehmilampi and Kortejärvi varve chronologies cover 5122 and 3902 years, respectively. For the whole sediment sequence, cumulative calculation errors in varve counting are estimated as +104 $(+2.1 \%)$ and $-114(-2.2 \%)$ varves for Lehmilampi and $+60(+1.5 \%)$ and $-59(-1.5 \%)$ for Kortejärvi. On average, annual sedimentation rate in the investigated sediments is $0.81 \mathrm{~mm} / \mathrm{yr}$ in both lakes. Precision in varve counting is good and comparable to those from other highquality varved lake sediments (e.g. Renberg et al., 1984; Zolitschka, 1991; Snowball et al., 1999; Ojala and Tiljander, 2003).

\section{Results of different normalisation methods for reconstructing relative palaeointensity}

In a sediment sequence with homogenous magnetic properties, normalisation of NRM by using any of the three concentration dependent parameters ( $\kappa$, ARM and SIRM) should yield a similar profile. Following Tauxe (1993) and Valet (2003), three relative palaeointensity estimates were calculated. The data after the $30 \mathrm{mT}$ AF demagnetisation step were used for $\mathrm{NRM}\left(\mathrm{NRM}_{30 \mathrm{mT}}\right)$ and ARM $\left(\mathrm{ARM}_{30 \mathrm{mT}}\right)$, by which secondary magnetisation components were completely demagnetised (Haltia-Hovi et al., 2010a). For normalisation by SIRM, the remanent magnetisation imparted at DC field of $1000 \mathrm{mT}\left(\mathrm{SIRM}_{1000 \mathrm{mT}}\right)$ was used. The resulting relative palaeointensity estimates, $\mathrm{NRM}_{30 \mathrm{mT}} / \kappa, \quad \mathrm{NRM}_{30 \mathrm{mT}} / \mathrm{ARM}_{30 \mathrm{mT}}$ and $\mathrm{NRM}_{30 \mathrm{mT}} / \mathrm{SIRM}_{1000 \mathrm{mT}}$, were normalised by the average of the core to allow comparisons between the different estimates. The three different relative palaeointensity candidates from Lehmilampi and Kortejärvi are shown in Fig. 4 and Fig. 5, respectively. Mean x-ray density reflecting sediment compositional variations, which appears critical for the interpretation of the relative palaeointensity results, is also presented. To provide a measure of the correlation between sediment composition and relative palaeointensity estimates, moving cross correlation was applied to determine the relation between the RPI estimates and relative mean-X-ray density (Fig. 6). Correlation coefficients (CCs) were calculated using a window of 200 years, and moving the window in 20 year increments along the time axis.

In Lehmilampi, $\mathrm{NRM}_{30 \mathrm{mT}} / \kappa$ and $\mathrm{NRM}_{30 \mathrm{mT}} / \mathrm{SIRM}_{1000 \mathrm{mT}}$ show largely similar millennial trends, where values increase between 5100 and 4000 yrs BP, with maximum intensity found between 2500 and $2600 \mathrm{yrs}$ BP and rapidly decreasing values after $1000 \mathrm{yrs}$ BP. The centennial variations have similar profiles, but the amplitude of changes is more pronounced in $\mathrm{NRM}_{30 \mathrm{mT}} / \kappa$. Correlation between sediment density and the palaeointensity estimates normalised by $\kappa$ is mostly negative correlation with moderate values (Fig. 6). 
$\mathrm{NRM}_{30 \mathrm{mT}} / \mathrm{ARM}_{30 \mathrm{mT}}$ shows somewhat differing behaviour, with smoothly increasing millennial trend until 2200 yrs BP, and thereafter decreasing values until present. The normalisation based on $\mathrm{ARM}_{30 \mathrm{mT}}$ shows rapid centennial oscillations, which appear to follow the variations in the sediment composition, where centennial peaks in the deposition of detrital matter coincide with higher values in $\mathrm{NRM}_{30 \mathrm{mT}} / \mathrm{ARM}_{30 \mathrm{mT}}$ (Fig. 4). CCs indicate moderate to high positive correlation between sediment density and $\mathrm{NRM}_{30 \mathrm{mT}} / \mathrm{ARM}_{30 \mathrm{mT}}$ (Fig. 6). In Kortejärvi (Fig. 5), $\mathrm{NRM}_{30 \mathrm{mT}} / \kappa$ and $\mathrm{NRM}_{30 \mathrm{mT}} / \mathrm{SIRM}_{1000 \mathrm{mT}}$ indicate increasing values until around $2600 \mathrm{yrs}$ BP, after which intensity shows a slowly and then at 800 yrs BP a rapidly decreasing trend. Moreover, $\mathrm{NRM}_{30 \mathrm{mT}} / \mathrm{\kappa}$ indicates another small maximum at $900 \mathrm{yrs}$ BP. Millennial and centennial variations are of larger amplitude and the centennial variations appear more pronounced in $\mathrm{NRM}_{30 \mathrm{mT}} / \kappa$, which shows a moderate to high negative correlation with sediment density as in Lehmilampi (Fig. 6). $\mathrm{NRM}_{30 \mathrm{mT}} / \mathrm{ARM}_{30 \mathrm{mT}}$ records moderate increase in palaeointensity between 3600 and $3000 \mathrm{yrs}$ BP, and cyclic variations between 2800 and $1000 \mathrm{yrs}$ BP. After this, this relative palaeointensity estimate indicates rapidly decreasing values until present. As in Lehmilampi, comparison of this relative palaeointensity estimate with sediment compositional variations indicates clearly positive correlation (Fig. 6). Such simple comparison provides preliminary evidence of environmental influence over the proposed relative palaeointensity records, which, instead of reflecting a purely geomagnetic signal, incorporate a lithological signal as well (Schwartz et al., 1996; Lund and Schwartz, 1999). Consequently, the coherence of the potential relative palaeointensity profiles with their normalisers was further tested with AnalySeries 2.0 software (Paillard et al., 1996), where Blackman-Tukey cross-spectral analysis with a Bartlett window was applied (Fig. 7). As expected, coherence above the $95 \%$ confidence limit between the palaeointensity estimate and the respective normaliser is observed in a broad range of frequencies especially in the relative palaeointensity estimates based on normalisation by $\kappa$ in both lakes. This indicates that $\mathrm{NRM}_{30 \mathrm{mT}} / \kappa$ should be excluded from further considerations on relative palaeointensity. $\mathrm{NRM}_{30 \mathrm{mT}} / \mathrm{ARM}_{30 \mathrm{mT}}$ appears to be more successfully normalised, but it is nevertheless coherent in several frequencies with $\mathrm{ARM}_{30 \mathrm{mT}}$. In the light of the results from cross-spectral analysis, the palaeointensity estimate $\mathrm{NRM}_{30 \mathrm{mT}} / \mathrm{SIRM}_{1000 \mathrm{mT}}$ is the least coherent with its normaliser in Lehmilampi. In Kortejärvi, the results from cross-spectral analysis suggest an incomplete normalisation of $\mathrm{NRM}_{30 \mathrm{mT}} / \mathrm{ARM}_{30 \mathrm{mT}}$ and $\mathrm{NRM}_{30 \mathrm{mT}} / \mathrm{SIRM}_{1000 \mathrm{mT}}$. Due to this evidently large-scale environmental bias, the value of the relative palaeointensity estimates from Kortejärvi is considered ambiguous, and therefore their use is avoided altogether. On the grounds of the results from cross-spectral analysis, $\mathrm{NRM}_{30 \mathrm{mT}} / \mathrm{SIRM}_{1000 \mathrm{mT}}$ appears to be the most reliable relative palaeointensity estimate from the sediments of Lehmilampi.

\section{Relative palaeointensity records with respect to magnetic grain size and lithological variations}

The difficulties encountered in isolating relative palaeointensity signal from the investigated sediments demonstrate that the fulfilled criteria of magnetic uniformity may not always result in a palaeointensity record of purely geomagnetic origin. Different factors may contribute to the complications encountered when applying the conventional normalisation techniques. Subtle shifts in magnetic grain size have been postulated to cause problems in reconstructing relative palaeointensity (Brachfeld and Banerjee, 2000). The deviations between the different normalisations reconstructed from sediments from Lehmilampi and Kortejärvi may derive from changes in magnetic grain size, the details of which are beyond the resolution of the set of magnetic analyses used in this work. Variations in sedimentary magnetic grain size may change in response to palaeoenvironmental changes, and they are influenced by several factors, such as the characteristics of detrital magnetic minerals derived from the catchment (Stockhausen and Zolitschka, 1999) and authigenic (in)organic formation of ferrimagnetic minerals (Pan et al., 2005; Ariztegui and Dobson, 1996). 
Magnetic susceptibility is largely free of grain size dependence in the SD fraction and larger, but yields considerably higher values in the superparamagnetic (SP) size fraction (Maher, 1988; Heider et al., 1996; Peters and Dekkers, 2003). Moreover, when the concentration of ferrimagnetic minerals is low, $\kappa$ may be controlled by paramagnetic minerals, which do not display remanence. The inverse relation between $\mathrm{NRM}_{30 \mathrm{mT}} / \kappa$ and sediment density variations (Fig. 7) probably reflects the presence of SP and MD magnetite and paramagnetic minerals in the magnetic record of these lakes. These minerals are presumed to originate from the catchment and are transported during periods of maximum discharge in spring. Use of isothermal remanent magnetisation as a normaliser is justified by the absence of paramagnetic contributions in it. Nevertheless, range of values in SIRM S $_{1000 \mathrm{mT}}$ is approximately an order higher than those found in NRM, indicating that $\mathrm{SIRM}_{1000 \mathrm{mT}}$ has activated magnetic fractions, such as large PSD and MD magnetite and/or other iron oxides, most likely haematite $\left(\mathrm{Fe}_{2} \mathrm{O}_{3}\right)$, which are not contributing to the stable NRM, but instead cause over-correction in normalisation.

In previous studies involving relative palaeointensity reconstructions from similar varved lake sediments in Finland and Sweden, the investigators have preferred the normalisation of NRM at a chosen demagnetisation step by ARM (Saarinen, 1998; Ojala and Saarinen, 2002; Snowball and Sandgren, 2002). This approach is appealing, because ARM activates the same magnetic grain population (SD to fine PSD) which carries the stable NRM signal (Levi and Banerjee, 1976). On the other hand, ARM is highly dependent on the magnetic grain size in submicron sized magnetite (King et al., 1983) and on the concentration of SD magnetite due to magnetic interactions (Sugiura, 1979). Higher concentration of single-domain magnetite in the more organic-rich parts of the sediment cause the positive correlation between $\mathrm{NRM}_{30 \mathrm{mT}} / \mathrm{ARM}_{30 \mathrm{mT}}$ sediment density in Lehmilampi and Kortejärvi. Magnetic assemblage in Lehmilampi sediments is postulated to be a mixture of magnetite of larger grain size derived from the catchment and SD bacterial magnetite, and the respective proportions of these components vary with time (Haltia-Hovi et al., 2010b). In a recent study, the accumulation of organic matter in Lehmilampi was suggested to respond to solar forcing during the last 2000 years (Haltia-Hovi et al., 2007). The correlation of mass-specific ARM and TOC in Lehmilampi, with high values found e.g. during the High Medieval (1100-900 yrs BP), may indicate a climatic control over magnetosome production (Haltia-Hovi et al., 2007). In case the regional climate is indirectly controlling the relative proportions of detrital and organic matter depositing in the lake bottom, the mineral magnetic assemblage mirrors the prevailing climate regime. Such subtle climatically driven shifts in bulk magnetic grain size may complicate normalisation of sediments for relative palaeointensity. SIRM $\mathrm{S}_{1000 \mathrm{mT}}$ may provide a more efficient normalisation for palaeointensity in these sediments, because it incorporates different magnetic grain sizes providing a more blurred estimate of magnetic concentration, whereas variations in $\mathrm{ARM}_{30 \mathrm{mT}}$ may be dependent on climatic variations. Snowball and Sandgren (2004) adopted normalisation by pseudo-Thellier technique in reconstructing relative palaeointensity from homogenous gyttja sediments in a Swedish lake. An advantage of this approach is that it allows observing discreet changes in coercivity and making of internal checks for reliability (Tauxe et al., 1995). Another aspect, by which the sediment compositional variations may influence relative palaeointensity, is that the processes related to the acquisition of NRM can biased by changes in sediment physical properties and deposition rates, resulting in a filtered geomagnetic signal (Valet and Meynadier, 1998; Mitra and Tauxe, 2009).

Selective dissolution of magnetite, which has been reported in anoxic and organic-rich lacustrine and marine environments, has been shown to cause complications in reconstructing relative palaeointensity records (Nowaczyk et al., 2001; Frank et al., 2002; Hayashida et al., 2007). In such environments, dissolution of magnetite can be suspected, when concentration of magnetic minerals descends with simultaneous shift to larger magnetic grain size, which may also coincide with a visible change in sediment lithology (Karlin and Levi, 1983; Karlin, 
1990; Anderson and Rippey, 1988; Snowball, 1993; Jelinowska et al., 1997). The available magnetic evidence from Lehmilampi does not suggest magnetite dissolution, but rather the opposite: organic-rich sediment sections are enriched in fine ferrimagnetic material, probably reflecting proliferation of magnetotactic bacteria during periods of abundant supply of nutrients. However, the contrast in magnetic properties in two sets of duplicate cores, KJ-A and KJ-B vs. KJ-I and KJ-II, from two coring sites in the same deep basin in Kortejärvi may point to selective dissolution of magnetite in the sediments in KJ-I and KJ-II (Haltia-Hovi et al., 2010a). Small but frequent occurrence of vivianite $\left(\mathrm{Fe}_{3}\left(\mathrm{PO}_{4}\right)_{2}\right)$ concretions in the sediments of both lakes indicates early reductive iron diagenetic changes (Berner, 1981), but its extent and influence over the sediment magnetic assemblage is not quantified.

The noise produced by unremoved local lithological effects in relative palaeointensity records may be smoothed out by stacking of records from different study sites (Snowball et al., 2007). Since Saarinen (1998), palaeomagnetic research in Finland and Sweden has been focused on varved sediment sequences deposited in small boreal lakes, with characteristics very similar to Lehmilampi and Kortejärvi. In case the response of these lakes to climatic variations would result in correspondent variations in lithology and consequently mineral magnetic properties, it is possible that some lithological biases could remain in the stacked record. However, other factors than climate influence mineral magnetic properties in lake sediments, such as the availability and characteristics of magnetic minerals in the catchment, airborne magnetic input, and authigenesis and dissolution of magnetic minerals, which complicate direct comparisons between different sediment records.

\section{Comparison of Lehmilampi relative palaeointensity estimate with absolute and relative palaeointensity records}

Environmental bias in the relative palaeointensity record $\mathrm{NRM}_{30 \mathrm{mT}} / \mathrm{SIRM}_{1000 \mathrm{mT}}$ from Lehmilampi, imprinting the centennial variations, has been clearly acknowledged. The competence of the millennial-scale relative palaeointensity variations can be tested by comparing it with other records, preferably those holding absolute palaeointensity. The record from Lehmilampi was compared with relative and absolute palaeointensity records from Europe (Fig. 8). The relative palaeointensity records are compiled from varved lake sediments as well, and they include a) Lake Pohjajärvi $\mathrm{NRM}_{30 \mathrm{mT}} / \mathrm{ARM}_{30 \mathrm{mT}}$ record from eastern Finland $\left(62^{\circ} 82^{\prime} \mathrm{N}, 28^{\circ} 04^{\prime} \mathrm{E}\right.$; Saarinen, 1998), b) Lake Nautajärvi $\mathrm{NRM}_{20 \mathrm{mT}} / \mathrm{ARM}_{20 \mathrm{mT}}$ record from central Finland $\left(61^{\circ} 48^{\prime} \mathrm{N}, 24^{\circ} 41^{\prime} \mathrm{E}\right.$; Ojala and Saarinen, 2002), and c) FENNORPIS, which is constructed by stacking NRM/ARM records from six varved lake sediment sequences (including the Lake Nautajärvi record) and one non-laminated sediment sequence, where relative palaeointensity was reconstructed by pseudo-Thellier technique $\left(57^{\circ}-64^{\circ} \mathrm{N}, 12^{\circ}-24^{\circ} \mathrm{E}\right.$; Snowball et al., 2007). In addition, archaeomagnetic data compilation presenting absolute palaeointensity data from e) Bulgaria and other countries in Europe and northern Africa (Kovacheva et al., 2009), f) Finland (Pesonen et al., 1995), and g) CALS7K.2 model output for Northern Karelia (Korte and Constable, 2005) were used in the comparison.

Comparing the morphologies of the different palaeointensity profiles reveals a largely similar trend of increasing intensity from 5000 yrs BP onwards with highest intensity found between 2800 and $2200 \mathrm{yrs}$ BP. Another high intensity feature occurs around $1000 \mathrm{yrs}$ BP, and it is particularly visible in the archaeomagnetic datasets and in Lake Pohjajärvi record. In Lehmilampi this palaeointensity feature seems subdued. Except for Lake Nautajärvi, all the records show a decreasing trend in palaeointensity starting approximately at $1000 \mathrm{yrs}$ BP. The decreasing relative palaeointensity in Lehmilampi during the last millennia is largely in line with archaeomagnetic palaeointensity results in Finland (Pesonen et al., 1995). CALS7K.2 model output compares favourably with Lehmilampi relative palaeointensity record. The general similarity, in particular when compared with the archaeomagnetic datasets, indicates that the sediments from Lehmilampi record the millennial trends in the geomagnetic 
palaeointensity during the last 5100 years. However, the centennial variations are responding to sediment lithology, which hampers their use as a relative record of geomagnetic field moment and comparisons with cosmogenic isotope records (St-Onge et al., 2003).

\section{Acknowledgements}

The authors wish to thank S. Putkinen (Geological Survey of Finland), H. Wenho, H. Jónsson and E. Puoskari (Department of Geology, University of Turku) for taking part in sediment coring. Two anonymous reviewers are acknowledged for their constructive comments, which helped to improve the manuscript. Ute Frank is thanked for her valuable comments on an earlier version of the manuscript. M. Korte is thanked for the CALSK7K model output for Northern Karelia, and M. Kovacheva is acknowledged for sending the latest archaeomagnetic dataset from Sofia. This study was funded by the Academy of Finland (Grant nos. 205805 and 123724), K.H. Renlund Foundation and The Centenary Foundation of Kymi Corporation, for which we are most grateful.

\section{R eferences}

Anderson, N.J, Rippey, B., 1988. Diagenesis of magnetic minerals in the recent sediments of a eutrophic lake. Limnol. Oceanogr. 33, 1476-1492.

Ariztegui, D., Dobson, J., 1996. Magnetic investigations of framboidal greigite formation: a record of anthropogenic environmental changes in eutrophic Lake St Moritz, Switzerland. Holocene 6, 235-241.

Beer, J., 2000. Long-term indirect indices of solar variability. Space Sci. Rev. 94, 53-66.

Berner, R.A., 1981. A new geochemical classification of sedimentary environments. J. Sed. Res. 51, 359-365.

Brachfeld, S.A., Banerjee, S.K., 2000. A new high-resolution geomagnetic relative paleointensity record for the North American Holocene: a comparison of sedimentary and absolute intensity data. J. Geophys. Res. 105 (B1), 821-834.

Channell, J.E.T., Xuan, C., Hodell, D.A., 2009. Stacking paleointensity and oxygen isotope data for the last 1.5 Myr (PISO-1500). Earth Planet. Sci. Lett. 283, 14-23.

Clark, A.J., Tarling, D.H., Noël, M., 1988. Developments in Archaeomagnetic Dating in Britain. Journal of Archaeological Science 15, 645-667.

Courtillot, V., Le Mouël, J.L., 1988. Time variations of the Earth's magnetic field: from daily to secular. Annu. Rev. Earth Planet. Sci. 16, 389-476.

Donadini, F., Kovacheva, M., Kostadinova, M., Casas, Ll., Pesonen, L.J., 2007. New archaeointensity results from Scandinavia and Bulgaria - Rock-magnetic studies inference and geophysical application. Phys. Earth Planet. Int. 165, 229-247. 
Frank, U., Nowaczyk, N.R., 2008. Mineral magnetic properties of artificial samples systematically mixed from haematite and magnetite. Geophys. J. Int. 175, 449-461.

Frank, U., Schwab, M., Negendank, J.F.W., 2003. Results of rock magnetic investigations and relative paleointensity determinations on lacustrine sediments from Birkat Ram, Golan Heights (Israel). J. Geophys. Res. 108(B8), 2379-2393.

Franke, C., Hofmann, D., von Dobeneck, T., 2004. Does lithology influence relative paleointensity records? a statistical analysis on South Atlantic pelagic sediments. Phys. Earth Planet. Int. 147, 285-296.

Geiss, C.E., Banerjee, S.K., Camill, P., Umbanhowar, C.E., Jr, 2004. Sediment-magnetic signature of land-use and drought as recorded in lake sediment from south-central Minnesota, USA. Quat. Res. 62, 117-125.

Guyodo, Y., Valet, J.P., 1999. Global changes in intensity of the Earth's magnetic field during the past 800 kyr. Nature 399, 249-252.

Haltia-Hovi, E., Nowaczyk, N., Saarinen, T., 2010a. Holocene palaeomagnetic secular variation recorded in multiple lake sediment cores from eastern Finland. Geophys. J. Int. 180, 609-622.

Haltia-Hovi, E., Nowaczyk, N., Saarinen, T., Plessen, B., 2010b. Magnetic properties and environmental changes recorded in Lake Lehmilampi (Finland) during the Holocene. J. Paleolimnol. 43, 1-13.

Haltia-Hovi, E., Saarinen, T., Kukkonen, M., 2007. A 2000-year record of solar forcing on varved lake sediment in eastern Finland. Quat. Sci. Rev. 26, 678-689.

Hayashida, A., Hattori, S., Oda, H., 2007. Diagenetic modification of magnetic properties observed in a piston core (MD01-2407) from the Oki Ridge, Japan Sea. Palaeogeogr.

Palaeoclimatol. Palaeoecol. 247, 65-73.

Heider, F., Zitzelsberger, A., Fabian, K., 1996. Magnetic susceptibility and remanent coercive force in grown magnetite crystals from $0.1 \mu \mathrm{m}$ to $6 \mathrm{~mm}$. Phys. Earth Planet. Int. 93, 239-256.

Helminen, V.A., 1987. Lämpöolot. In: P. Alalammi (Editor). Atlas of Finland, Climate, vol. 131. National Board of Survey and Geographical Society of Finland, Helsinki, pp. 4-10 (in Finnish).

Jelinowska, A., Tucholka, P., Wieckowski, K., 1997. Magnetic properties of sediments in a Polish lake: evidence of a relation between the rock-magnetic record and environmental changes in Late Pleistocene and Holocene sediments. Geophys. J. Int. 129, 727-736.

Karlin, R., 1990. Magnetite diagenesis in marine sediments from the Oregon continental margin. J. Geophys. Res. 95, 4405-4419.

Karlin, R., Levi, S., 1983. Diagenesis of magnetic minerals in Recent haemipelagic sediments. Nature 303, 327-330.

Katari, K., Bloxham, J., 2001. Effects of sediment aggregate size on DRM intensity: a new theory. Earth Planet. Sci. Lett. 186, 113-122. 
Katari, K., Tauxe, L., 2000. Effects of $\mathrm{pH}$ and salinity on the intensity of magnetization in redeposited sediments. Earth Planet. Sci. Lett. 181, 489-496.

Kent, D.V., 1973. Post-depositional remanent magnetization in deep-sea sediment. Nature 246, 32-34.

Kim, B., Kodama, K., Moeller, R., 2005. Bacterial magnetite produced in water column dominates lake sediment mineral magnetism: Lake Ely, USA. Geophys. J. Int. 163, 26-37.

King, J.W., Banerjee, S.K., Marvin, J., 1983. A new rock magnetic approach to selecting sediments for geomagnetic paleointensity studies: application to paleointensity for the last 4000 years. J. Geophys. Res. 88, 5911-5921.

Kok, Y., 1999. Climatic influence in NRM and ${ }^{10}$ Be-derived geomagnetic paleointensity data. Earth Planet. Sci. Lett. 166, 105-119.

Korte, M., Constable, C.G., 2005. Continuous geomagnetic field models for the past 7 millennia: 2. CALSK7K. Geochem. Geophys. Geosyst. 6, Q02H16, doi:10.1029/2004GC000801.

Kovacheva, M., Boyadziev, Y., Kostadinova-Avramova, M., Jordanova, N., Donadini, F., 2009. Updated archeomagnetic data set of the past 8 millennia from the Sofia laboratory, Bulgaria. Geochem. Geophys. Geosyst. 10, Q05002, 6 pp, doi:10.1029/2008GC002347.

Kovacheva, M., Hedley, I., Jordanova, N., Kostadinova, M., Gigov, V., 2004. Archaeomagnetic dating of archaeological sites from Switzerland and Bulgaria. J. Archaeol. Sci. 31, 1463-1479.

Levi, S., Banerjee, S.K., 1976. On the possibility of obtaining relative paleointensities from lake sediments. Earth Planet. Sci. Lett. 29, 219-226.

Lu, R., Banerjee, S.K., Marvin, J., 1990. The effects of clay mineralogy and the electrical conductivity of water on the acquisition of depositional remanent magnetization in sediments. J. Geophys. Res. 95, 4531-4538.

Lund, S.P., Schwartz, M., 1999. Environmental factors affecting geomagnetic field paleointensity estimates from sediments. In: B. Maher and R. Thompson (Editors). Quaternary Environmental Magnetism. Cambridge University Press, Cambridge, pp. 324-351.

Luukkonen, E.J., 2005. Pre-Quaternary rocks of the Nurmes map sheet area. Geological map of Finland, sheet 4321. Geological Survey of Finland, Espoo.

Maher, B.A., (1988). Magnetic properties of some synthetic sub-micron magnetites. Geophys. J. 94, 83-96.

Meynadier, L., Valet, J-P, Bassinot, F.C., Shackleton, N.J., Guyodo, Y. 1994. Asymmetrical saw-tooth pattern of the geomagnetic field intensity from equatorial sediments in the Pacific and Indian Oceans. Earth Planet. Sci. Lett. 126, 109-127.

Mitra, R., Tauxe., L., 2009. Full vector model for magnetization in sediments. Earth Planet. Sci. Lett. 286, 535-545. 
Nowaczyk, N., Harwart, S., Melles, M., 2001. Impact of early diagenesis and bulk particle grain size distribution on estimates of relative geomagnetic palaeointensity variations in sediments from Lama Lake, northern Central Siberia. Geophys. J. Int. 145, 300-306.

Ojala, A.E.K., Saarinen, T., 2002. Paleosecular variation of the Earth's magnetic field during the last 10000 years based on the annually laminated sediment of Lake Nautajärvi, central Finland. Holocene 12, 391-400.

Ojala, A.E.K., Saarnisto, M., 1999. Comparative varve counting and magnetic properties of the 8400-yr sequence of an annually laminated sediment in Lake Valkiajärvi, Central Finland. J. Paleolimnol. 22, 335-348.

Ojala, A.E.K., Tiljander, M., 2003. Testing the fidelity of sediment chronology: comparing varve and paleomagnetic results from Holocene lake sediments from central Finland. Quat. Sci. Rev. 22, 1787-1803.

Paasche, Ø, Løvlie, R., Dahl, S.O., Bakke, J., Nesje, A., 2004. Bacterial magnetite in lake sediments: late glacial to Holocene climate and sedimentary changes in northern Norway. Earth Planet. Sci. Lett. 223, 319-333.

Paillard, D., Labeyrie, L., Yiou, P., 1996. Macintosh program performs time-series analysis. EOS Transactions, AGU 77, p. 379.

Pan, Y., Petersen, N., Davila, A.F., Zhang, L., Winklhofer, M., Liu, Q., Hanzlik, M., Zhu, R., 2005. The detection of bacterial magnetite in recent sediments of Lake Chiemsee (southern Germany). Earth Planet. Sci. Lett. 232, 109-123.

Pesonen, L.J., Leino, M.A.H., Nevanlinna, H., 1995. Archaeomagnetic Intensity in Finland during the Last 6400 Years: Evidence for a Latitude-Dependent Nondipole Field at $\sim$ AD 500. J. Geomagn. Geoelec. 47, 19-40.

Peters, C., Dekkers, M. J., 2003. Selected room temperature magnetic parameters as a function of mineralogy, concentration and grain size. Phys. Chem. Earth 28, 659-667.

Renberg, I., Segerström, U., Wallin, J.-E., 1984. Climatic reflection in varved lake sediments. In: N.-A. Mörner and W. Karlén (Editors). Climatic Changes on a Yearly to Millennial Basis. Reidel Publishing Company, Dordrecht, pp. 249-256.

Richter, C., Venuti, A., Verosub, K.L., Wei, K., 2006. Variations of the geomagnetic field during the Holocene: relative paleointensity and inclination record from the West Pacific (ODP Hole 1202B). Phys. Earth Planet. Int. 156, 179-193.

Saarinen, T., 1998. High-resolution palaeosecular variation in northern Europe during the last 3200 years. Phys. Earth Planet. Int. 106, 299-309.

Schwarz, M., Lund, S.P, Johnson, T., 1996. Environmental factors as complicating influences in the recovery of quantitative geomagnetic-field paleointensity estimates from sediments. Geophys. Res. Lett. 23, 2693-2696.

Shcherbakov, V.P., Shcherbakova, V.V., 1983. On the theory of depositional remanent magnetization in sedimentary rocks. Geophys. Surv. 5, 369-380. 
Snowball, I.F., 1993. Geochemical control of magnetite dissolution in subarctic lake sediments and the implications for environmental magnetism. J. Quat. Sci. 8, 339-346.

Snowball, I.F., 1994. Bacterial magnetite and the magnetic properties of sediments in a Swedish lake. Earth Planet. Sci. Lett. 126, 129-142.

Snowball, I., Muscheler, R. 2007. Palaeomagnetic intensity data: An Achilles heel of solar activity reconstructions. Holocene 17, 851-859.

Snowball, I., Sandgren, P., 2002. Geomagnetic field variations in northern Sweden during the Holocene quantified from varved lake sediments and their implications for cosmogenic nuclide production rates. Holocene 12, 517-530.

Snowball, I., Sandgren, P., 2004. Geomagnetic field intensity changes in Sweden between 9000 and 450 cal BP: extending the record of "archaeomagnetic jerks" by means of lake sediments and the pseudo-Thellier technique. Earth Planet. Sci. Lett. 227, 361-376.

Snowball, I., Sandgren, P., Petterson, G., 1999. The mineral magnetic properties of an annually laminated Holocene lake-sediment sequence in Northern Sweden. Holocene 9, 353362.

Snowball, I., Zillén, L., Ojala, A., Saarinen, T., Sandgren, P., 2007. FENNOSTACK and FENNORPIS: Varve dated Holocene palaeomagnetic secular variation and relative palaeointensity stacks for Fennoscandia. Earth Planet. Sci. Lett. 255, 106-116.

Snowball, I., Zillén, L., Sandgren, P., 2002. Bacterial magnetite in Swedish varved lakesediments: a potential bio-marker of environmental change. Quat. Int. 88, 13-19.

Stern, D.P., 2002. A millennium of geomagnetism. Rev. Geophys. 40, 1-30.

Stockhausen, H., Zolitschka, B., 1999. Environmental changes since 13,000 cal. BP reflected in magnetic and sedimentological properties of sediments from Lake Holzmaar (Germany). Quat. Sci. Rev. 18, 913-925.

St-Onge, G., Stoner, J.S., Hillaire-Marcel, C., 2003. Holocene paleomagnetic records from St. Lawrence Estuary, eastern Canada: centennial- to millennial-scale geomagnetic modulation of cosmogenic isotopes. Earth Planet. Sci. Lett. 209, 113-130.

Sugiura, N., 1979. ARM, TRM and magnetic interactions: Concentration dependence. Earth Planet. Sci. Lett. 42, 451-455.

Tauxe, L., 1993. Sedimentary records of relative paleointensities of the geomagnetic field: theory and practice. Rev. Geophys. 31, 319-354.

Tauxe, L., Pick, T., Kok, Y.S., 1995. Relative paleointensity in sediments: a pseudo-Thellier approach. Geophys. Res. Lett. 22, 2885-2888.

Teanby, N., Laj, C., Gubbins, D., Pringle, M., 2002. A detailed palaeointensity and inclination record from drill core SOH1 on Hawaii. Phys. Earth Planet. Int. 131, 101-140. 
Thouveny, N., Creer, K., Williamson, D., 1993. Geomagnetic moment variations in the last 70000 years, impact on production of cosmogenic isotopes. Global Planet. Change 7, 157172.

Tucker, P., 1981. Palaeointensities from sediments: normalization by laboratory redepositions. Earth Planet. Sci. Lett. 56, 398-404.

Valet, J.-P., 2003. Time variations in geomagnetic intensity. Rev. Geophys. 41(1), 1004.

Valet, J.-P., Meynadier, L., 1998. A comparison of different techniques for relative paleointensity. Geophys. Res. Lett. 25, 89-92.

Weeks, R.J., Laj, C., Endignoux, L., Mazaud, A., Labeyrie, L., Roberts, A.P., Kissel, C., Blanchard, E., 1995. Normalised natural remanent magnetisation intensity during the last 240 000 years in piston cores from the central North Atlantic Ocean: geomagnetic field intensity or environmental signal? Phys. Earth Planet. Int. 87, 213-229.

Williams, T., Thouveny, N., Creer, K.M., 1998. A normalised intensity record from Lac du Bouchet: geomagnetic palaeointensity for the last 300 kyr? Earth Planet. Sci. Lett. 156, 33-46.

Zolitschka, B., 1991. Absolute dating of late Quaternary lacustrine sediments by high resolution varve chronology. Hydrobiologia 214, 59-61. 


\section{Table and figure captions}

Table 1. Information on sediment cores from Lehmilampi and Kortejärvi discussed in the present study. *PP-corer is a lighter type of Kullenberg piston corer $* *$ only the upper and varved part of the core LL-I (total length $748 \mathrm{~cm}$ ) from Lehmilampi is discussed here

Table 2. Summary on magnetic measures and procedures

Figure 1. A) Location of the investigated lakes in Eastern Finland, B) Kortejärvi and C) Lehmilampi. Coring sites for the individual cores are marked in B) and C). Numbers denote depth (m) in the deepest point of the basin.

Figure 2. Mineral magnetic properties of core LL-I from Lehmilampi during the last 5100 years. See subsection 3.1 for explanation of the magnetic parameters. Total organic carbon (TOC), expressed in weight percentage, is also shown to facilitate comparison between magnetic parameters and concentration of organic matter.

Figure 3. Mineral magnetic properties of core KJ-A from Kortejärvi during the last 3700 years. See subsection 3.1 for explanation of the magnetic parameters.

Figure 4. Relative palaeointensity estimates from Lehmilampi core LL-I together with sediment relative mean $\mathrm{x}$-ray density, where annual data is shown as a grey line and the superimposing black line is a 31 -year running average to provide smoothing for the highfrequency variations in the annual deposition.

Figure 5. Relative palaeointensity estimates from Kortejärvi core KJ-A together with sediment relative mean $\mathrm{x}$-ray density, where annual data is shown as a grey line and the superimposing black line is a 31-year running average to provide smoothing for the highfrequency variations in the annual deposition.

Figure 6. Moving cross correlation of relative mean x-ray density and the three relative palaeointensity estimates for Lehmilampi (filled grey line) and Kortejärvi (black line). Investigated time window is 200 years and increment 20 years. $\mathrm{CC}=$ correlation coefficient.

Figure 7. Coherence between RPI estimates and normalisers in Lehmilampi (a, b, and c) and Kortejärvi (d, e, and f). The dashed lines indicate the $95 \%$ confidence limit. None of the calculated RPI estimates is free from environmental bias, but the coherence is significantly reduced when using SIRM $_{1000 \mathrm{mT}}$ in Lehmilampi (c).

Figure 8. Relative and absolute palaeointensity estimates from Europe. For references for the data presented in a-c and e-g, see the text. For Lake Pohjajärvi, Lake Nautajärvi, and Bulgarian archaeomagnetic data, original data is plotted with grey line and the black line denotes a 5-point running average. The grey line in Lehmilampi represents the original data and the black line denotes a 150-year running average. The associated $95 \%$ confidence limits are included with FENNORPIS. The associated error in the archaeomagnetic data from Finland are shown as well. 
A)

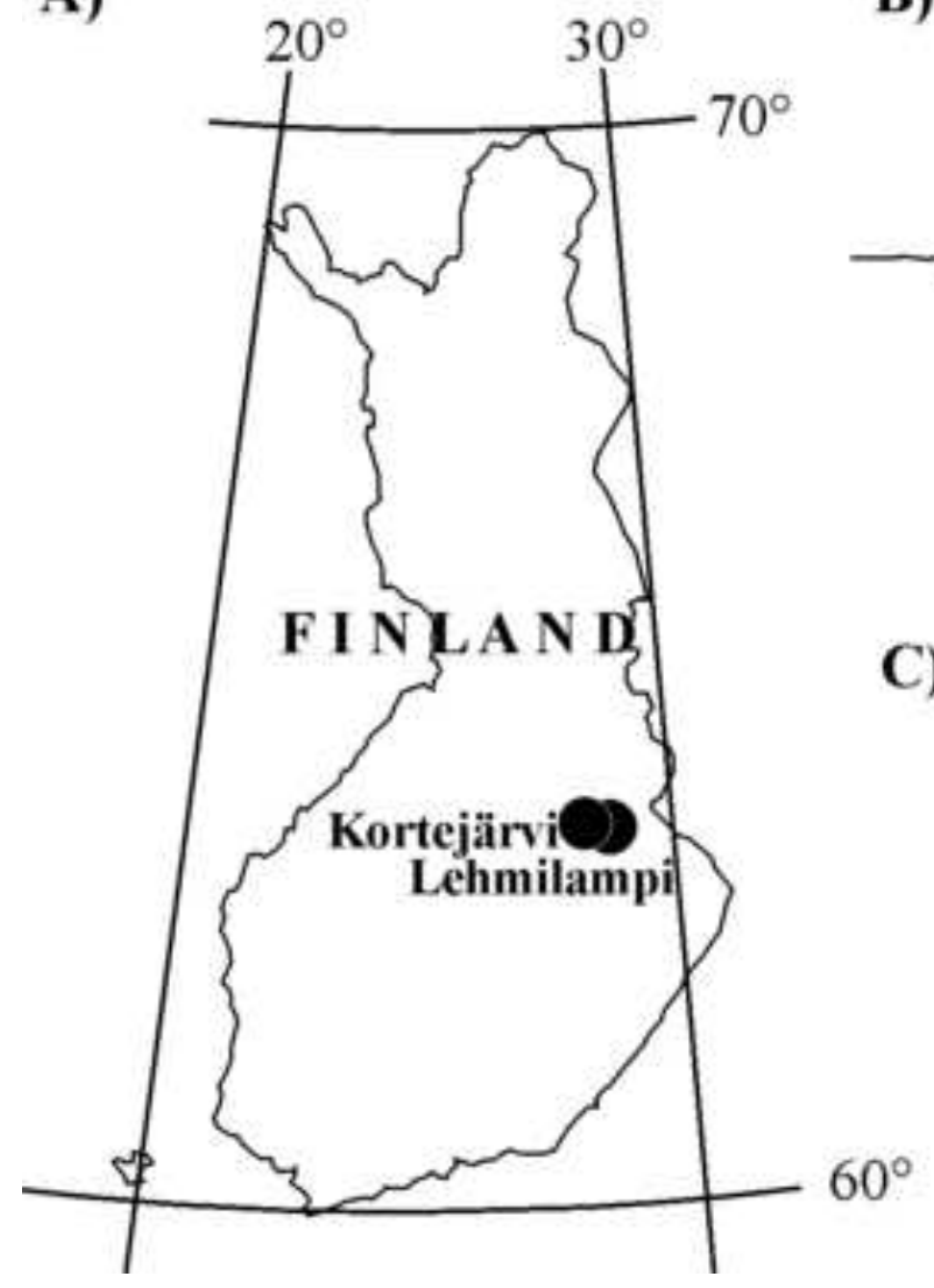

B)

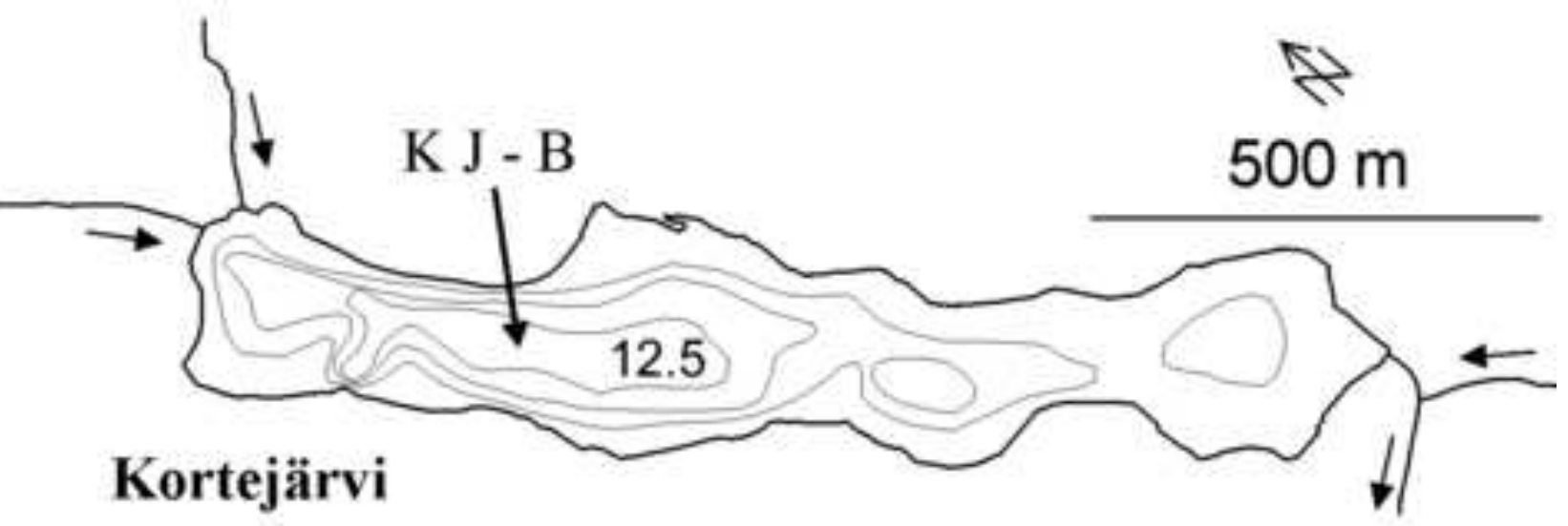

C)

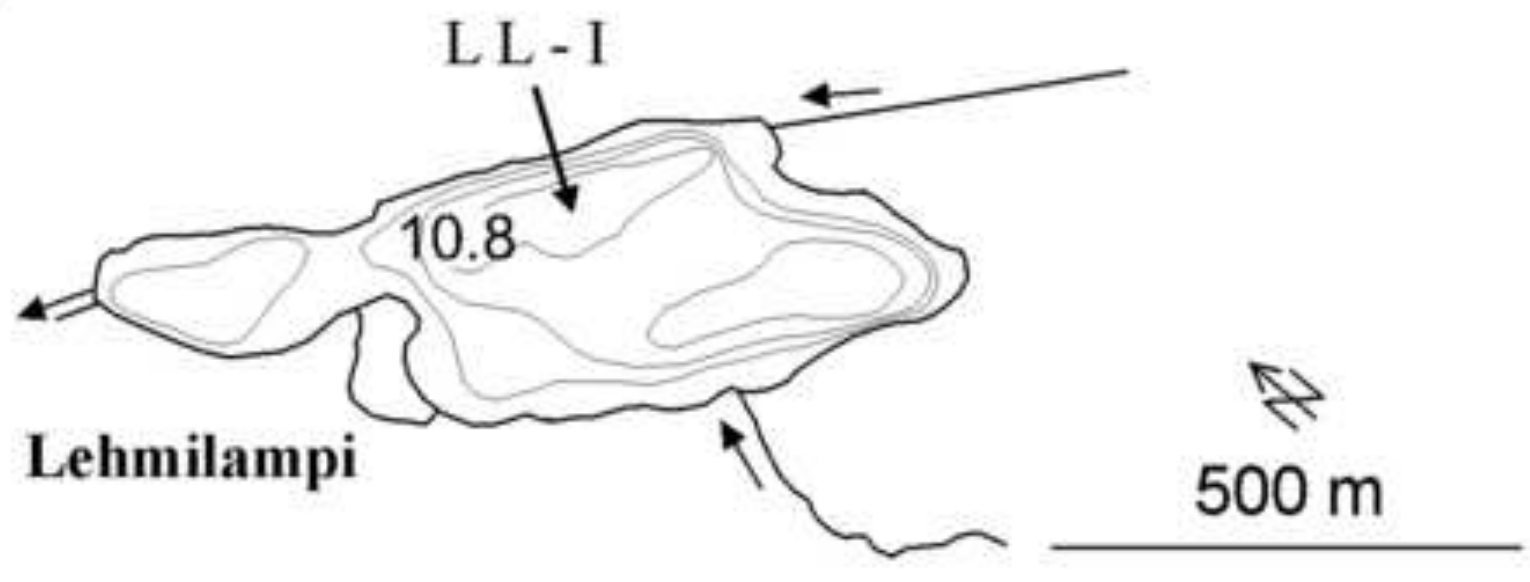




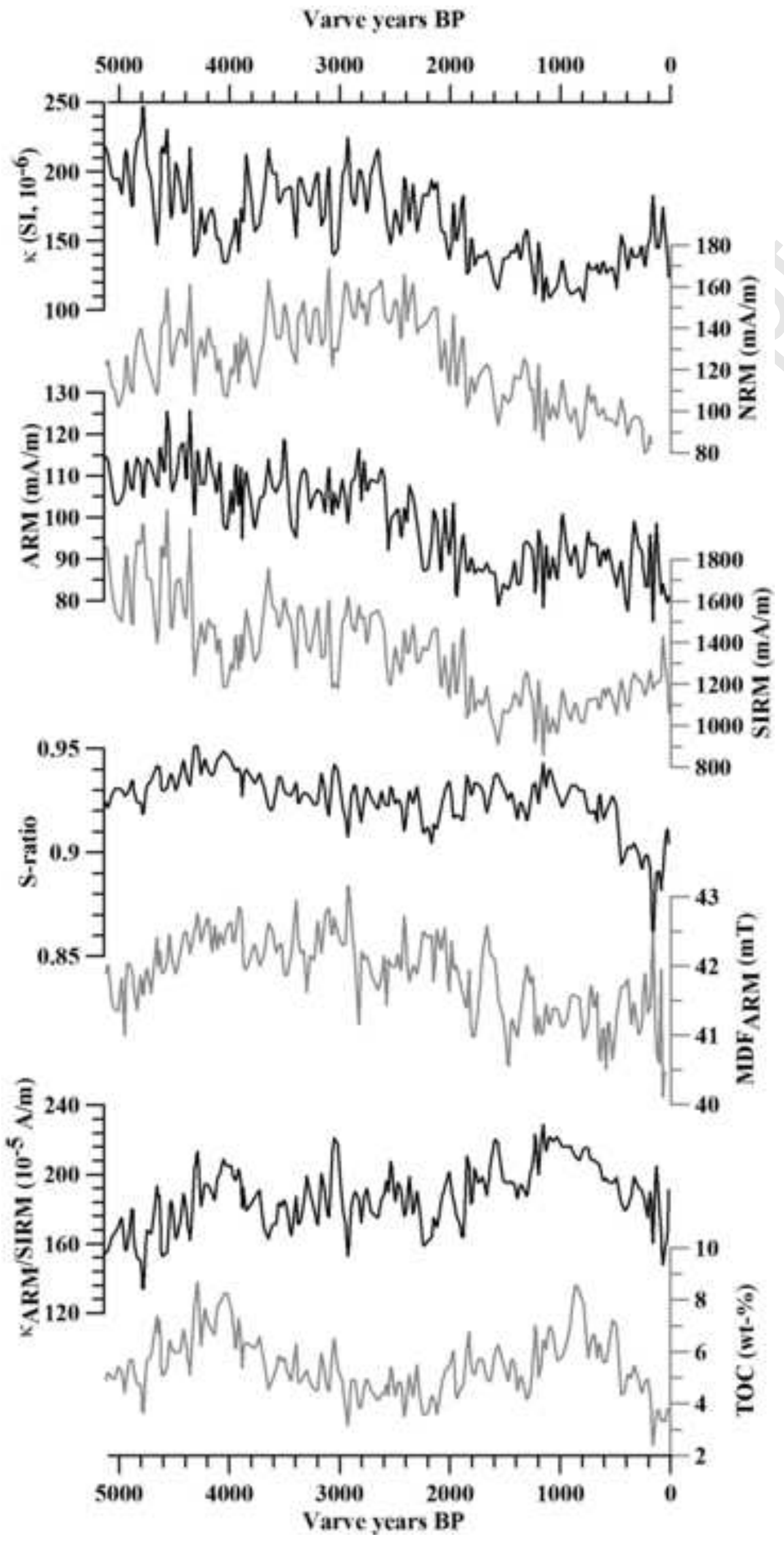




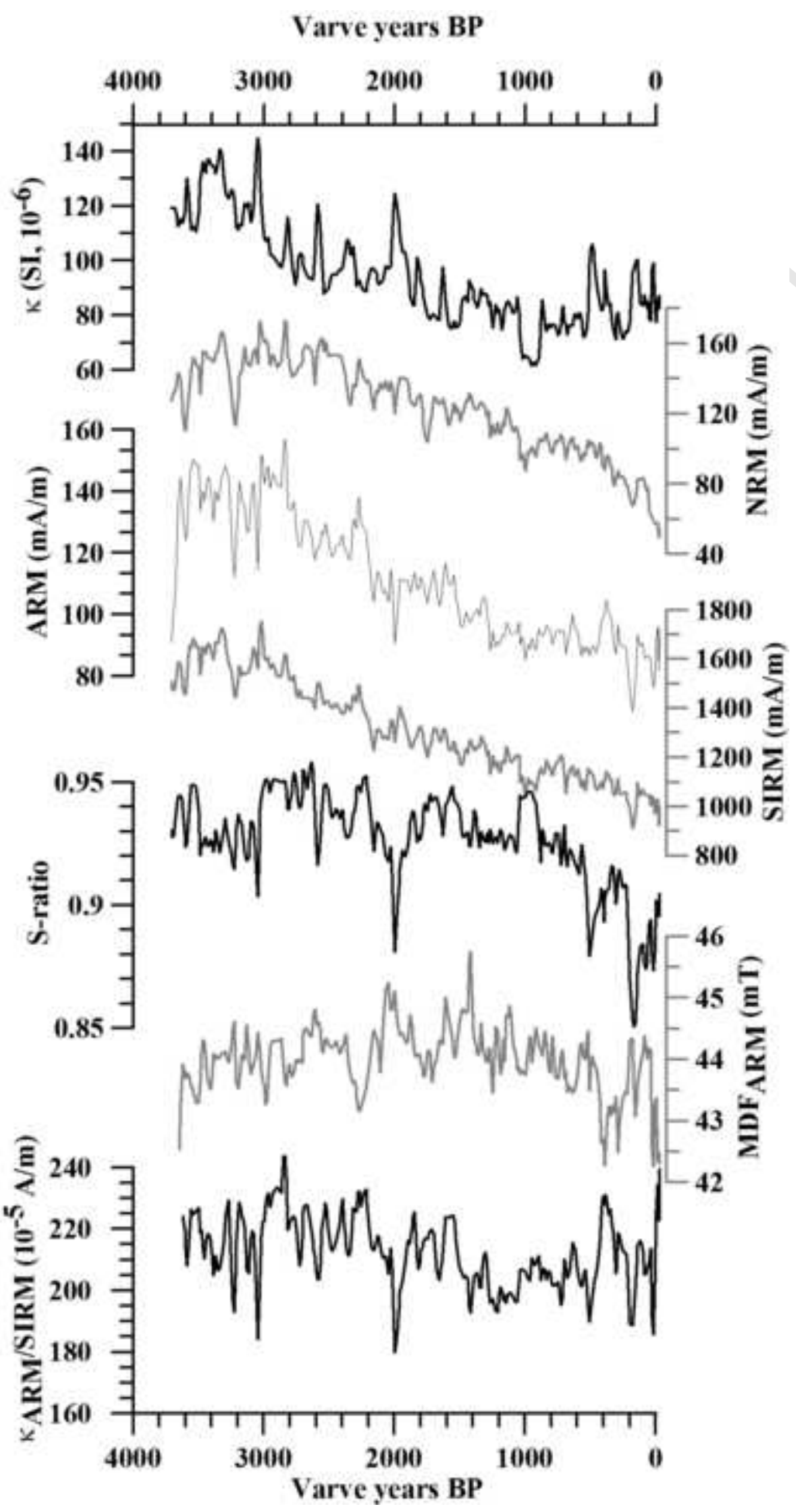




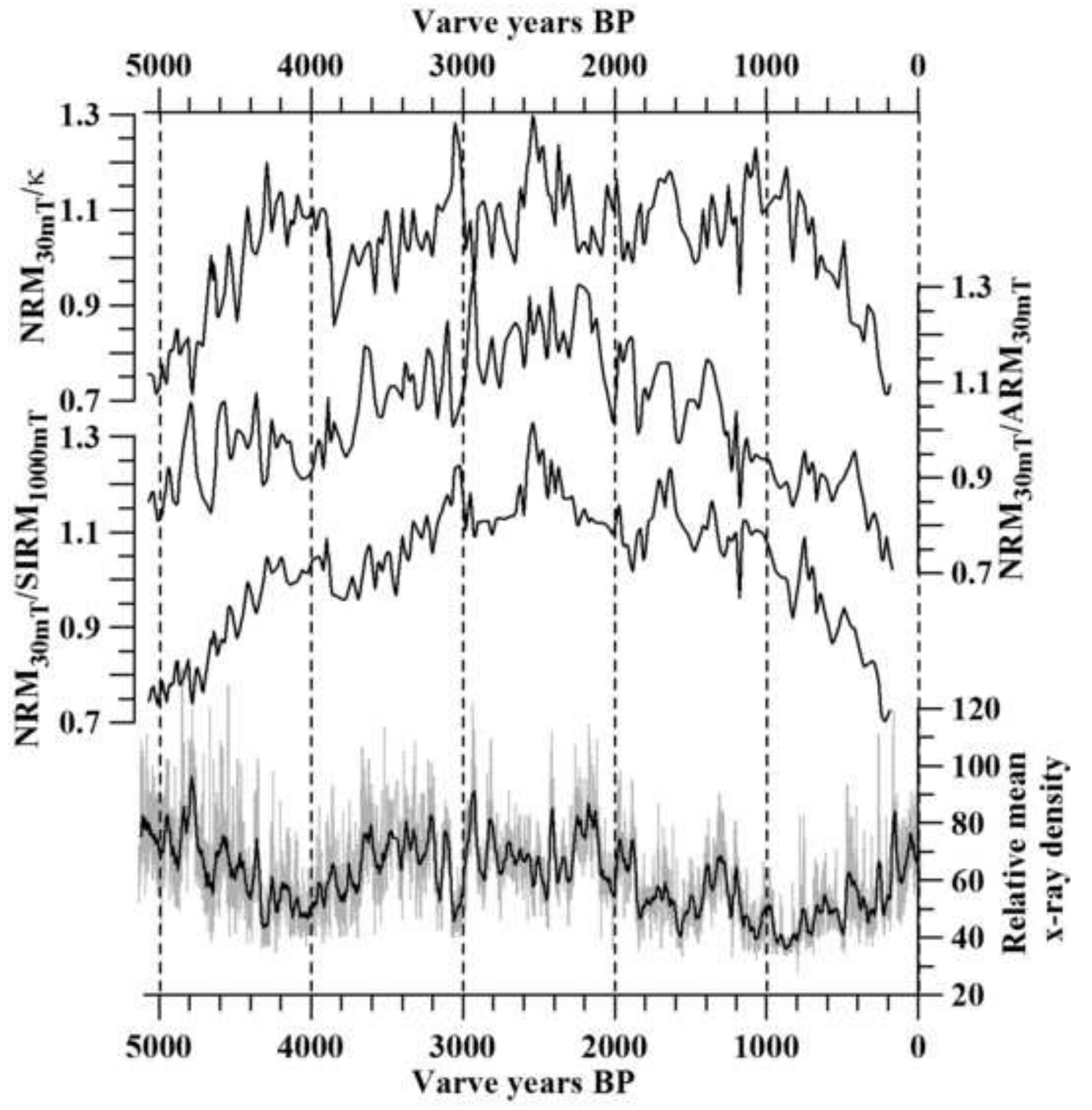




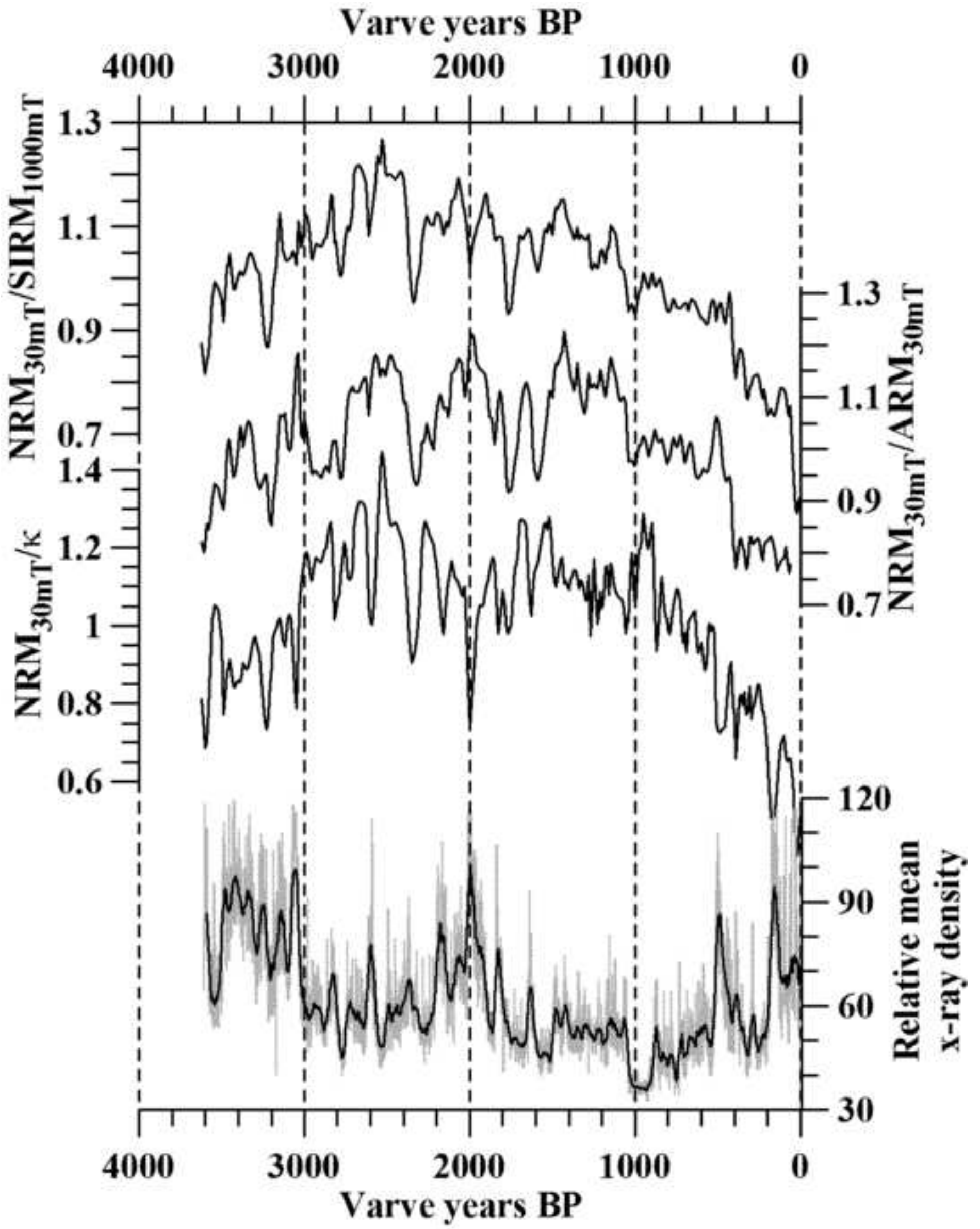




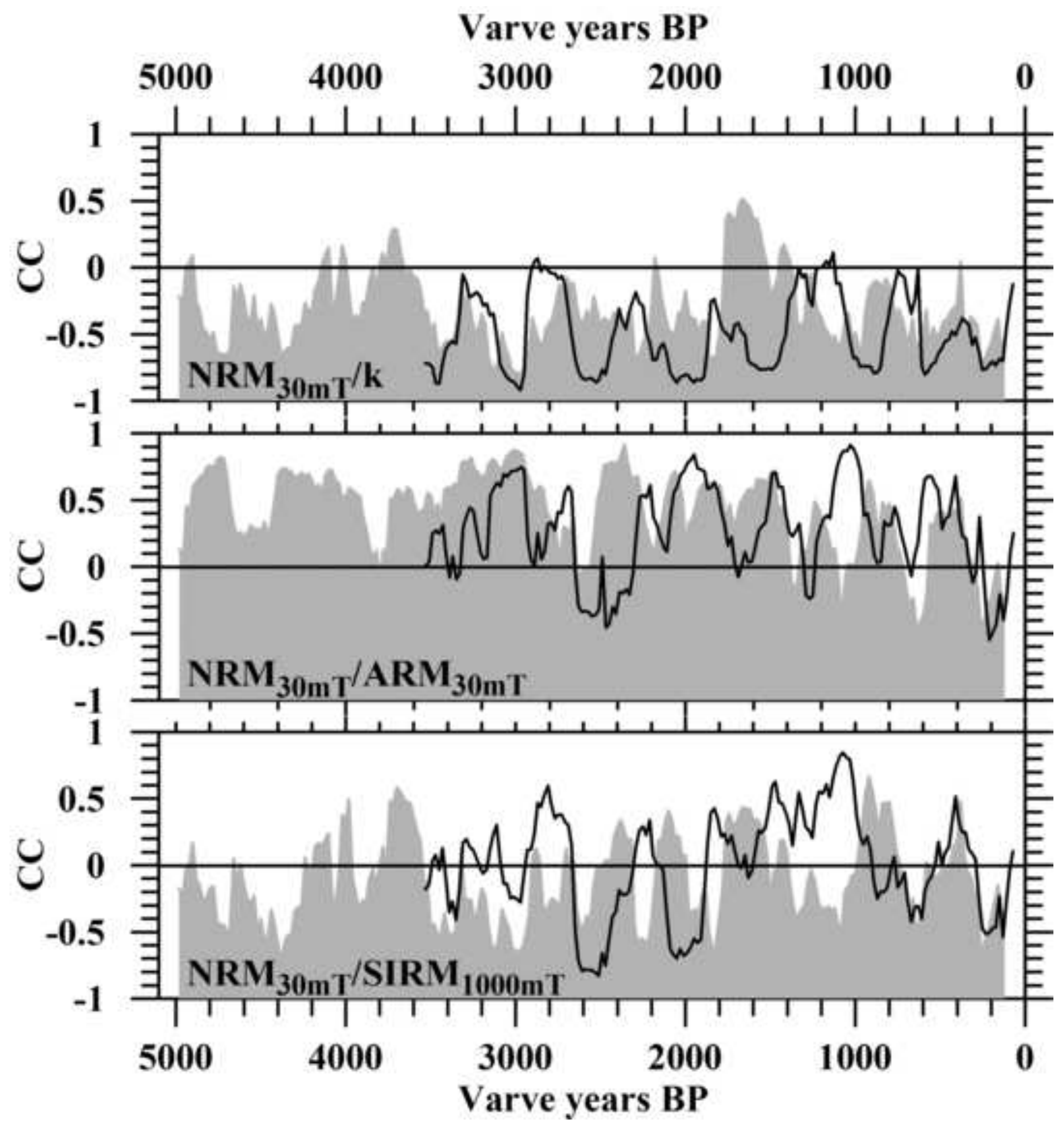




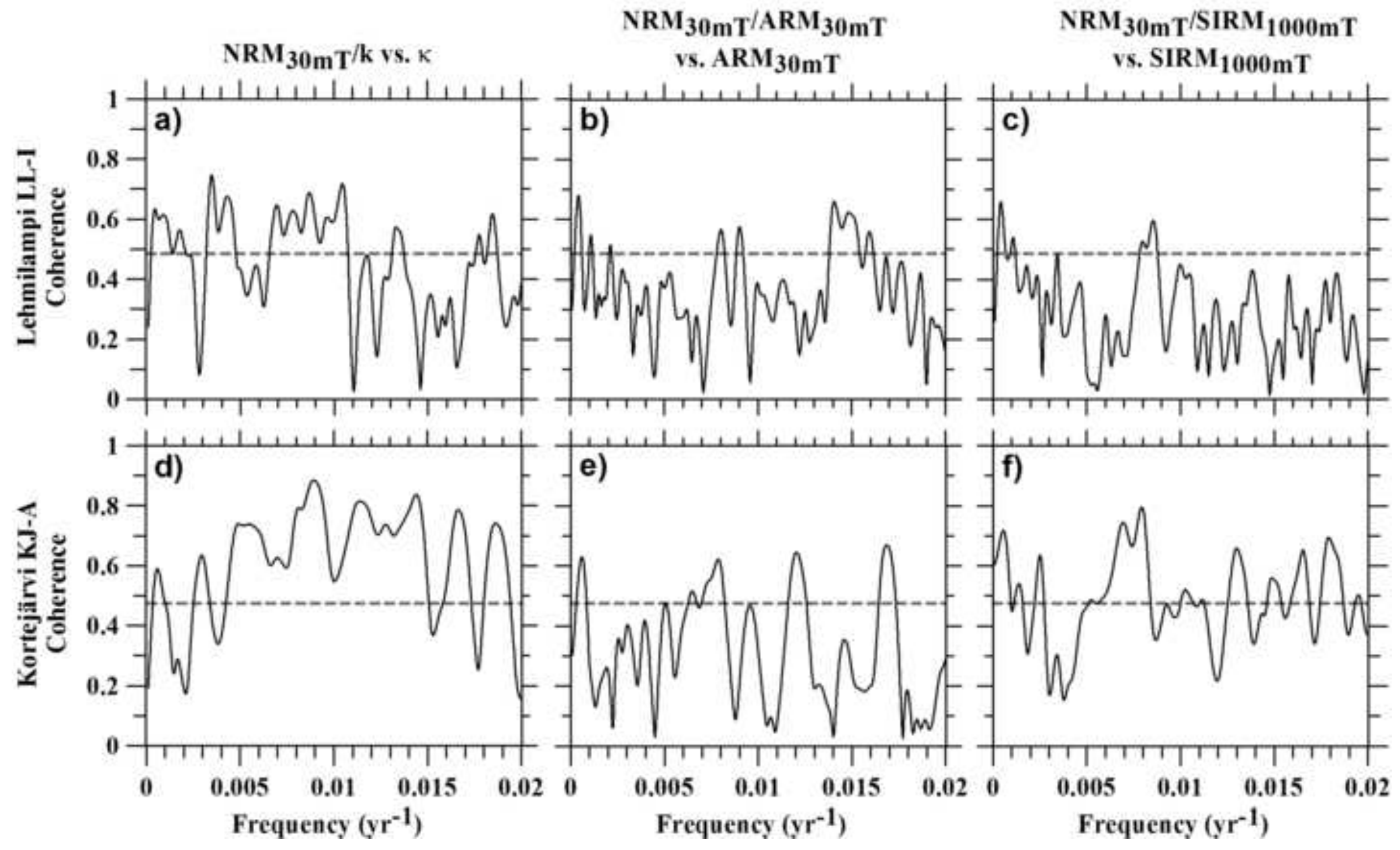




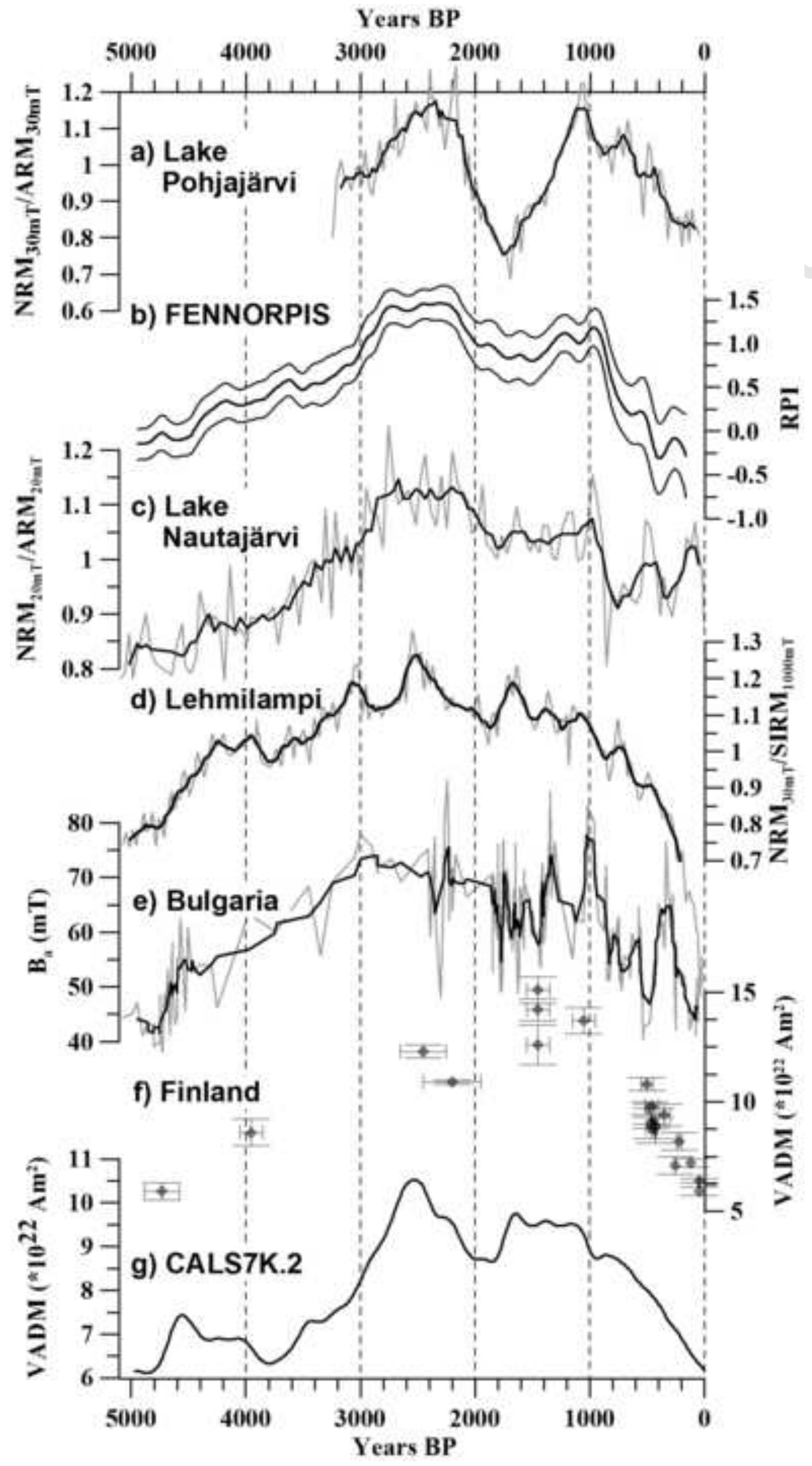




$\begin{array}{llllll}\text { Lake } & \text { Core Coring tool } & \begin{array}{l}\text { Investigated } \\ \text { section }(\mathbf{c m})\end{array} & \begin{array}{l}\text { Water depth } \\ (\mathbf{m})\end{array} & \text { Coring time } & \begin{array}{l}\text { N:o } \\ \text { sam }\end{array} \\ \text { Lehmilampi LL-I } & \text { PP-corer* } & 0-415^{* *} & 10.80 & 2 / 2006 & 178 \\ \text { Kortejärvi } & \text { KJ-A Piston corer } & 0-300 & 12.05 & 4 / 2006 & 228\end{array}$




\section{Measurement type}

Low field magnetic

susceptibility ( $\kappa$ )

Natural remanent

magnetization (NRM)

Demagnetization of NRM

Imprinting of anhysteretic remanent magnetization (ARM)

Measurement of ARM

Demagnetization of ARM

Imprinting of isothermal remanent magnetization

$\left(\mathrm{IRM}_{1000 \mathrm{mT}} ; \mathrm{IRM}_{-0.1 \mathrm{mT}}\right)$

Measurement of IRMs

\section{Instrument}

AGICO Kappabridge KLY-3S

$2 \mathrm{G}$ Enterprises cryogenic

magnetometer (2G 755 SRM)

In-line triaxial alternating field demagnetizer of the $2 \mathrm{G} 755$ SRM

2G Enterprises 600 single-axis demagnetizer including an ARM-coil

$2 \mathrm{G}$ Enterprises cryogenic magnetometer (2G 755 SRM)

In-line triaxial alternating field demagnetizer of the $2 \mathrm{G} 755$ SRM

2G Enterprises 660 pulse magnetizer

Molyneux Minispin fluxgate

magnetometer

\section{Details}

In 10 steps up to $100 \mathrm{mT}(5,10,15$, $20,30,40,50,65,80,100 \mathrm{mT}$ )

$\mathrm{DC}$ field $0.05 \mathrm{mT}$, peaking $\mathrm{AF}$ amplitude $100 \mathrm{mT}$

In 5 steps to $50 \mathrm{mT}$ at $10 \mathrm{mT}$ intervals 